\title{
10. Papua as an Islamic Frontier: Preaching in 'the Jungle' and the Multiplicity of Spatio-Temporal Hierarchisations
}

\author{
Martin Slama
}

This contribution attempts to examine accounts of Papua that perceive the territory as a frontier where borders of nation states, civilising missions, predatory capitalism and violent conflicts converge, and to which images of the stone-age, the primitive, the uncivilised, etc. are so persistently attached. The anthropology of Indonesia has generated particularly rich accounts of frontier regions including valuable theorisations of the concept (e.g. Li 1999; Rutherford 2003; Tsing 2005). This chapter engages with these approaches by understanding Papua not only as a frontier in the sense that has been discussed in the literature so far, but also by exploring decentred, non-Western perspectives. Whereas Engseng Ho (2004) in a seminal piece investigated 'empire through diasporic eyes' and revealed fascinating historic parallels between European colonial empires in the Indian Ocean and the current global empire of the United States, this chapter takes a diasporic perspective on the Papuan frontier - the diasporic eyes belonging to Muslims with a particular trans-regional history. Such as in the case described by Ho (2004), the diaspora in question is formed by Muslims of Arab descent originating from the Hadhramaut, a south-eastern territory of today's Republic of Yemen, who have crossed the waters of the Indian Ocean and the Indonesian archipelago since medieval times (Freitag and Clarence-Smith 1997; Jonge and Kaptain 2002; Ho 2006). Boosted by the opening of the Suez Canal and the advent of steam shipping, their migration to Indonesia reached its height from the middle of the nineteenth to the middle of the 20th century. It substantially decreased after Indonesia's independence due to nationalistic policies and economic uncertainties in the early post-colonial period. Today, Hadhramis form distinct communities in Indonesia and are particularly engaged in trade and Islamic proselytising not only in the country's centres but also on its peripheries (Slama 2011), including Papua.

Investigating the manifold entanglements of Islam and capitalism in the peripheries of the Malay world, Joel Kahn (2012: 26) asserts: 'It was/is in these commercially dynamic "frontier" zones that Muslims - merchants, traders, entrepreneurs, artisans and cash croppers on the one hand; holy men, religious teachers, and missionaries on the other - have played very significant, active and 
constructive roles since the beginning of the modern era.' Hadhramis exemplify the Muslims to which Kahn refers, especially with regard to their roles in eastern Indonesia where they managed to become persistent players in the local power structure from colonial to present times (Clarence-Smith 1998; Slama 2011). In fact, from the beginning of their diasporic engagements, Hadhramis' eyes did not only spot imperial centres of power but also their marginal frontiers - and their perceptions and intentions clearly differed from Western ones. As a result, travelling with Hadhramis to Papua, as this chapter intends to do, indicates the influential force and, at the same time, the limits of Western notions of the frontier, thereby revealing multiple forms of spatio-temporal hierarchisation. The chapter thus explores Papua as an Islamic frontier based on perspectives that differ and, at the same time, borrow from prior conceptualisations.

How Indonesian frontiers have so far been defined, is aptly summarised by Tania Murray Li (2001: 41): 'In Indonesia, it is the interior of the larger islands and the smaller islands of the eastern part of the archipelago that are usually characterised as culturally distinct frontiers incompletely inscribed by civilization, world religions, and the power of governing regimes.' Li (1999: 16), who draws on her research in upland Central Sulawesi, also speaks of 'frontier zones' that are made accessible by logging roads attracting new migrants with the result of increasing state control over people and resources. Li's discussion thus comprises two aspects of the frontier that are salient in the literature at large: as a (neo)colonial project aimed at 'pushing back the frontier of civilization' as well as 'a metaphor for national development in its material and ideological senses' concerned with 'spatial expansion and delimitation' (Fold and Hirsch 2009: 95).

Inspired by her research in Kalimantan, Anna Tsing (2005: 28) theorises the temporal and spatial dimensions of the frontier that can give rise to imaginaries upon which this chapter - and indeed the whole volume - is focused:

A frontier is an edge of space and time: a zone of not yet - not yet mapped, not yet regulated. It is a zone of unmapping: even in its planning, a frontier is imagined as unplanned. Frontiers aren't just discovered at the edge, they are projects in making geographical and temporal experience. Frontiers make wildness, entangling visions and vines and violence; their wildness is both material and imaginative. This wildness reaches backward as well as forward in time, bringing old forms of savagery to life in the contemporary landscape. Frontiers energize old fantasies, even as they embody their impossibilities.

One of these imaginaries, as McCarthy and Cramb (2009: 113-114) note, concerns the alleged 'backwardness' of those who inhabit the frontier being contrasted with modern agricultural techniques in the case of oil palm expansion, of which Papua is a major target area. 
Being associated with the stone-age, Papua occupies a special place in these imaginaries by exemplifying the most extreme form of backwardness in evolutionist/developmental discourse as well as in accounts of wilderness in Western travel writing. Rupert Stasch (2011: 7; see also Stasch in this volume) examined the latter discourse that sensationally depicts Papua as 'one of the last great wilderness areas in the world', 'one of the earth's last true frontiers' or as 'the final frontier in an ever-shrinking world'. As examined in the introduction to this volume in more detail, such discourses display a hierarchy of primitivisation and thus a hierarchy of frontiers relegating Papua to the lowest civilizational and spatio-temporal level.

Obviously, such accounts of Papua, which heavily resonate within Indonesia, stand in sharp contrast to how many Papuans appropriate 'civilization' and imagine themselves in the world - and to how Islam constitutes frontiers (as we will see below). Danilyn Rutherford's (2003: 19) study of Biak notions of the foreign recognises 'an ideology that ... turned what is foreign into a source of agency and an object of desire'. This is particularly expressed in the myth of Koreri, which Rutherford reads 'as a utopia: an imagined state of pleasure and perfection' (ibid. 25) 'evoking frontiers that are not only spatial but also conceptual' such as between Biak and Indonesia (ibid. 26). The myth climaxes in a millennial return of a messiah-like figure called Manermakeri indicating the advent of a paradisiacal condition 'when the foreign and the local converge' and frontiers collapse (Rutherford 2003: 26). Furthermore, Koreri also inspired reinterpretations of Christian narratives - and Islamic ones (as we will see below): 'Koreri prophets claimed to have discerned the Bible's secret significance: it was a rendering of Biak myth. Jesus Christ was really Manermakeri' (Rutherford 2012: 157-158). By relocating the Bible's central figure to Papua, this belief in a 'Papua Jesus' heavily undermines the evolutionist logic of the stone-age image. It turns Papua into the source of a 'world religion' rather than into a territory of exemplary backwardness. Similarly, among the Yali in the eastern highlands of Papua, Eben Kirksey (2012: 8-10) recorded a narrative about the beginning of time when 'whites' and 'blacks' lived happily together and all goods from electric generators to rice were available in abundance in Papua. But then the whites disappeared into a hole in the earth taking with them all the goods. Being able to seize foreign power, reveal foreign power's Papuan origin, or show that Papua was already part of a modern world (as in the Yali case), these examples attest to rich Papuan discourses that run counter to images of Papua as a wild, deficient, yet-to-be developed stone-age frontier (see also Timmer in this volume).

However, the stone-age is only one notion in the Western repertoire of spatiotemporal hierarchisation. Since this chapter is occupied with Islamic ways of seeing peripheral regions, one should not pass over the fact that the Islamic 
world itself became subject to Western othering that in some cases is particularly built around imaginaries of a frontier between the 'orient' and the 'occident' (Gingrich 2010). In the course of orientalist perceptions that rest upon dynamics of positive and negative stereotyping (Baumann 2004), Muslim societies are often equated with the Middle Ages and thus also relegated back in time; or they are kept at a 'distance' in spatial terms (Heiss and Feichtinger 2013). Long before the emergence of modern European discourses of temporal and spatial degradation, however, Muslims have developed their own concepts of the frontier. Let me thus refer to notions of the frontier as they can be deduced from the rich sources of Islamic scholarship, after which I will ask to what extent Islamic perspectives challenge imaginaries of the frontier, as discussed so far, and how these perspectives attest to the multiplicity of spatio-temporal hierarchisations that one can find in Indonesia today.

\section{Islamic frontier notions}

In the 8th century $\mathrm{CE}, \mathrm{Abu}$ Hanifa, after whom the Hanafi school of law was named, introduced the term Dar al-Islam, 'house of Islam' or 'abode of Islam', for territories that were under Islamic rule. The lands reigned over by Muslim leaders also became known under its synonym Dar as-Salam or 'house of peace'. Marking the borders of the Islamic world, Dar as-Salam was used to characterise Muslim realms at the peripheries of the Islamic world such as Daressalam in East Africa or Brunei Darussalam and Aceh Darussalam in Southeast Asia (see also Ahmad 1976). The territories bordering Dar as-Salam are called Dar al-Harb or 'House of War', 'whose leaders are called upon to convert to Islam', as the Oxford Dictionary of Islam explains; and when they 'accept Islam, the territory becomes part of dar al-Islam, where Islamic law prevails'. ${ }^{1}$

Yet apart from this territorial definition of a frontier, another prominent concept in Islamic thought illustrates a notion of frontier defined not by space but by time. Whereas the distinction between Dar as-Salam and Dar al-Harb was introduced by scholars of jurisprudence in medieval times, the jahiliyyah - literally 'ignorance' - is mentioned in the Qur'an, referring to pre-Islamic Arabia as an age of idolatry when ignorance of divine guidance prevailed. In the 20th century the concept was revived by various Muslim thinkers, most notably by the Egyptian Muslim Brotherhood intellectual Sayyid Qutb, who saw a reappearance of jahiliyyah in many Muslim countries as a result of the lack of observance of Islamic law. This view entails a considerable reinterpretation of the concept, since 'it means neither a particular period in time, before or after Islam, nor a particular place, race or state or society. It is, rather, a condition of

1 The Oxford Dictionary of Islam, see: http://www.oxfordislamicstudies.com/article/opr/t125/e490. 
any time and place where Allah is not held to be the highest governmental and legal authority' (Khatab 2006: 3). This extension of the concept to other times and places than pre-Islamic Arabia makes it also relevant for contemporary Islamic discourses in Indonesia, as we will see. However, 20th-century reinterpretations of the concept, as will also become clear below, do not necessarily lead to the dissolution of the temporal hierarchy between an un-Islamic and a fully implemented Islamic order.

Throughout Islamic history one finds influential figures exploring the frontiers of the Islamic world pointing to the 'ever-changing, porous boundaries' that form the social background of a legal concept that, as Travis Zadeh (2011: 87) emphasises, rests upon a clear demarcation between 'two realms, divided between the lands of peace and lands of war, [that] stand as mirror images of each other'. Before Hadhramis became major players in the Indian Ocean it was Ibn Batutta (1304-1386 or 1377) who in some instances crossed these porous boundaries and travelled to places that later also became intersections of Hadhrami networks. Ross Dunn (2005: 6-7) indicates how the frontiers of the Islamic world affected the routes of Muslim travellers like Ibn Batutta and his successors:

Ibn Batutta ... spent most of his travelling career within the cultural boundaries of what Muslims called the Dar al-Islam, or Abode of Islam. This expression embraced the lands where Muslims predominated in the population, or at least where Muslim kings or princes ruled over non-Muslim majorities and where in consequence the shari' $a$, or Sacred Law, of Islam was presumably the foundation of the social order. In that sense Islamic civilization extended from the Atlantic cost of West Africa to Southeast Asia.

Yet Dunn (ibid.) also mentions those Muslims who formed communities outside this continent-spanning zone of Islam: 'Moreover, important minority communities of Muslims inhabited cities and towns in regions such as China, Spain, and tropical West Africa that were beyond the frontiers of the Dar alIslam.' As indicated above, Ibn Batutta visited some of these Muslim communities outside the Dar al-Islam - and he did particularly so in East and Southeast Asia, as the following quote from his Rihla (travelogue) confirms: 'I then proceeded for one and twenty days through his [a Muslim ruler's] dominions, after which we arrived at the city of Mul Java, which is the first part of the territories of the infidels' (Lee 2004 [1829]: 201). ${ }^{2}$

2 I am grateful to my colleague Johann Heiss (Institute for Social Anthropology at the Austrian Academy of Sciences) who discussed with me Ibn Batutta's account which he can read in the original Arabic version. There Ibn Batutta uses the phrase 'bilad al-kuffar' translated as 'territories of the infidels' for the Dar al-Harb. Johann Heiss also informed me that, contrary to what the translator Rev. Samuel Lee believed in 1829, the 
Similar to Ibn Batutta, Hadhramis were also producers of texts that comprised itineraries and travelogues of their frontier explorations (Alatas 2005). Ho (2006: 55 ) has analysed these accounts by pointing to the central role they occupied in the formation of the Hadhrami diaspora:

For the itineraries that feature so prominently as a basic genre element within these accounts created effects that go beyond the ambitions of positivist historical reconstruction. In telling of the travels of various figures, they created a discourse of frontiers that ultimately transformed landscapes. The discursive effect ... was to transform a place from a destination to an origin.

So when Hadhrami 'travelers open up frontier lands' (ibid.) they transformed those lands through settling and establishing concrete manifestations of Islam such as mosques and graves. And they preferably did so among populations that they saw as having not yet or not yet sufficiently embraced Islam. This brings us to another important difference between Western and Islamic concepts of the frontier, as revealed by Ho (ibid.):

Unlike the 19th-century American idea of Manifest Destiny, frontiers in Hadhrami sayyid ${ }^{3}$ discourses of mobility are not devoid of people but full of them. Newcomers such as the sayyids found places for themselves - as educators - in lands that were already full. This theme has been a constant one throughout the Hadrami diaspora around the Indian Ocean, beginning with Hadramawt itself in the early days.

By travelling along and sometimes transcending the boundaries of the Dar alIslam, Hadhramis were not looking for land but for people. Moreover, their approach suggests that they regarded those they came across as contemporaries and not as representatives of past times. Hierarchy was constructed through stressing noble descent, Islamic knowledge and practice, and not through attaching oneself to a supposedly superior age. In addition to that, reciprocal, more egalitarian relations were established through trade. And when they travelled to 'lands that were already full', for the male Hadhrami migrants ${ }^{4}$ this meant that they were also full of women, i.e. of potential marriage partners. These three factors - trade, proselytisation and marriage - can also be discerned in Hadhramis' roles in the Islamisation of parts of Papua, as the next paragraphs give attention to the question of how Papua became an Islamic frontier in the first place.

current state of research doubts that Ibn Batutta really visited Java. Rather, it is much more likely that 'the city of Mul Java' refers to a place in Sumatra, an island which was at that time largely inhabited by non-Muslims, whereas the vast majority of its population today adheres to Islam.

3 Sayyid (pl. sada) is a title for descendants of the Prophet Muhammad.

4 Hadhrami travellers and migrants were almost exclusively men, as Hadhrami society knows heavy restrictions on female mobility (Slama 2012). 


\section{Papua as an Islamic frontier}

The first contacts between Papuans and Muslim traders must have occurred in the 15 th century or even earlier, though this is difficult to determine due to the lack of historical evidence. However, it is clear that in the 17th century two regions in eastern Indonesia became crucial for the spread of Islam to the coastal parts of Papua, i.e. the northern Moluccas with its four sultanates (Ternate, Tidore, Bacan and Jailolo), among which Tidore was most significant with regard to Papua, and eastern Seram and its adjunct Geser-Gorom archipelago from where Muslim traders developed exclusive economic ties with Papuans of the Bird's Head and Bomberai peninsulas. The sultanate of Tidore exemplifies the Dar asSalam/Dar al-Harb frontier pattern of Islamic rulers developing relations with their non-Islamic neighbours eventually resulting in the conversion of the latter. In the 17th century, Tidore increasingly drew its attention towards Papua when the Dutch East India Company (VOC) largely took over its lucrative spice trade. As a sort of compensation, Tidore 'was granted the exclusive right to trade with the "Papuan Islands"" (Warnk 2010: 114). This was a tributary trade in natural goods and slaves, asserting Tidorese authority in the waters east of Halmahera and along the coast of the Bird's Head Peninsula. As a result, as Holger Warnk (ibid. 129) concludes, 'by the mid-17th century the first chiefs in the Raja Ampat Islands had probably been converted to Islam', and, Dutch sources stated, 'in 1705 ... the leaders of Waigeo, Misol and Salawati were Muslims' (ibid. 116).

These Tidore-Raja Ampat ties became particularly pronounced during the revolt of Prince Nuku at the end of the 18th century, when Prince Nuku rebelled against the Dutch and their policy to degrade Tidore to the status of vassalage. He mobilised forces from Raja Ampat, Seram and Halmahera, and diplomatically approached the British. In the course of the conflict, as Muridan Widjojo (2009: 57) has revealed, Nuku was proclaimed 'Sultan Papua and Seram' and called himself 'King of Papua' in a letter to the Dutch. From this strategy of turning tributary trade relations into political support and symbolic power, Widjojo (2009: 215) draws fascinating historical parallels: 'For centuries local ritual and economic ties bound Maluku to Papua. The irony of Nuku's career is that so far nobody has successfully pointed out that, thanks to this Papuan connection, he was able to beat the Dutch at their own game [of playing off powers against each other]. He did so skillfully making use of the English just as the Soekarno Government made use of the United States in 1962 and the United Nations in 1963.'

In the frontier zone of eastern Seram and Geser-Gorom trade with the Papuans from the Bird's Head and Bomberai peninsulas, where conversions to Islam were reported for the mid-17th century (Warnk 2010: 115), were not imbued with sultan-like authority. 'The Serammers were concerned mostly with trading access rather than symbolic power ... they traded rather than raided', as Roy 
Ellen (2003: 122) emphasised in his illuminating study of their trading network, which is based on an institution called sosolot: 'bays and anchorages in which one polity maintained a recognised monopoly in trade' (ibid. 126). East Seram and Geser-Gorom polities had thus exclusive access to particular trade domains that became increasingly Islamic due to these connections that were further fostered by inter-marriages. Whereas first mosques in the region are confirmed for the 1870s (Warnk 2010: 125), for the 1820s a Dutch expedition reported that the Muslims in the region 'had no mosques or prayer houses and did not fast, they were able to recite the first sura, bury their deceased according to Muslim customs, and did not eat pork or turtle' (ibid. 120). This account of only partial observance of Islamic provisions indicates the ambivalent status of these Islamic pockets of Papua with regard to whether they can be regarded as part of the Dar al-Islam, a theme that we will encounter also in today's perceptions of the region.

The sultanate of Tidore also maintained tributary trade relations along the northern coast of Papua, particularly with Papuans of the northern Bird's Head, Biak-Numfor and the Cenderawasih Bay. When Biak seafarers paid homage to the sultan at his court, as Rutherford (2003: 17) has pointed out, they 'claimed that they were absorbing barak, the Biak version of the Arabic word for the magical power that pervaded the sultan's person and surroundings'. One can hardly say to what extent these relations also resulted in the conversion of Papuans to Islam, since today the Papuan population of these regions is overwhelmingly Christian. But at least some chiefs converted. According to Warnk (2010: 122), there is evidence for Papuan Muslims in Dorey Bay, close to where Manokwari is now located, before 1850. Ironically, when the German missionaries Ottow and Geissler held their first Christian services in Dore in 1855 in the Malay language, they 'were attended by several local Muslim chiefs who spoke Malay fairly well' (ibid. 124). So what is today celebrated as the coming of Christianity to Papua, also reflected in the adoption of the by-name 'gospel city' (kota injil) by Manokwari in post-Suharto Indonesia, was not a coming to a monotheistically 'empty land', but rather to an Islamic frontier where Papuan and Islamic visions had already met before. This earlier religious encounter might have also contributed to the fact that the efforts of Ottow and Geissler were not met with much success, and 'it was not until after 1900 that mass conversions to Christianity occurred in the Cendrawasih Bay and Biak region' (ibid.). This was also the time when Christianity was introduced in Raja Ampat and the Bird's Head and Bomberai peninsulas, the two major regions where Islam has gained a foothold among Papuans. For the latter, Ellen (2003: 144) asserts that with 'the establishment of a Dutch post in Fak-fak in 1898, the influence of Seram Laut traders and Islam declined, and that of Christian missions and the Chinese grew'. However, trade between the Serammers and Papuans went on and only 
substantially declined after Indonesia's independence when trade between the newly established republic and Netherlands New Guinea was not allowed (see Kaartinen 2010: 59).

With regard to Hadhrami Arabs, as William Clarence-Smith (1998: 43) has argued, they were particularly strong in trade in the Moluccas 'in the third quarter of the nineteenth century, at a time when neither Chinese nor European competitors showed much interest in these distant marches of the Dutch empire' (see also Spyer 2000: 12). Their presence can be understood as a consequence of the overall increase of Hadhrami migration to Southeast Asia fuelled by the opening of the Suez Canal in 1869 and the introduction of steam shipping in the Indian Ocean. From the Moluccas some of them moved to Papua. For the turn from the 19th to the 20th century it is confirmed that Arab traders resided in Kaimana, Fakfak and Kokas (Ellen 2003: 143). Similar to the Serammers, they sometimes took Papuan wives (Warnk 2010: 127). With the Alkatiry and Alhamid as their leading families, Hadhramis had indeed a strong basis among the Muslims in eastern Seram and Geser-Gorom (Ellen 1996, 2003: 253-54). Their influence can be felt until today, especially in the realm of religion, since 'in the Geser-Gorom area we find that families of Arab descent often provide the imam, even if the majority of the population is not ethnically Arab' (Ellen 2003: 265). One of Ellen's Hadhrami interlocutors in Tual who lived for a long time in Geser proudly stated in the 1980s 'that his grandfather was the first to convert Papuans to Islam' (ibid. 238).

Almost 30 years after Ellen's research such narratives are still firmly embedded in Hadhrami family stories in the region. $\mathrm{Pak}^{5}$ Umar, who is in his fifties, was born and grew up in Seram and resides now in Ambon where he told me of his grandfather who came from the Hadhramaut to the Netherlands East Indies. After a stay in Surabaya his grandfather went to South Sulawesi, then to Ambon and finally to Fakfak, marrying daughters of local leaders (anak raja). Especially with regard to Fakfak, he explained that his ancestors contributed to the spread of Islam because 'they married daughters of chiefs that were not yet Muslims; as a consequence, slowly but surely they became Muslims and their people followed them. This was the great way of spreading Islam at that time!' ${ }^{6}$ It was Pak Umar's father who married a daughter of a Serammer chief. Being of Arab descent, Pak Umar emphasises his high status in the family of his mother: 'When the chief there [on Seram] wants to do something, he will surely ask me first. There is no difference between us, being of Arab descent, and the local people. Unlike the Chinese, the Japanese or the Dutch who brought their wives with them, we Arabs did not. ${ }^{7}$

5 In Indonesian 'Pak' (short form of 'bapak'), literally 'father', is a respectful form of address for married men. 6 Interview in Ambon, Moluccas, 19 June 2012. All interviews were conducted in Indonesian. All translations are by the author.

7 ibid. 
We see here how Hadhramis became highly integrated into the local societies of this Moluccan-Papuan realm without abandoning their Arab identity, which is highlighted through boasting their roles in converting Papuans to Islam. In these accounts, Papua features as a frontier in the sense that it is on the way to becoming, or has already become, part of the Dar al-Islam, thanks to the efforts of exemplary Muslims, a status Hadhramis like to claim for themselves. Differing from Western notions of the frontier based on evolutionist/developmentalist discourses, in these accounts, spatio-temporal hierarchies are less pronounced. When Muslim rulers are finally followed by their people, their polities will become part of the Dar al-Islam and the 'age of idolatry' immediately ends, regardless of how Papua is perceived from the outside. I want to proceed with examples of such outside perceptions, as they are widespread among Muslims in Indonesia residing west of this zone of close contact and mixing of the Moluccas, the Raja Ampat islands and the Bird's Head and Bomberai peninsulas. An analysis of their discourses will reveal how the frontier status of Papua within the Indonesian nation-state is informed by Islamic views and also how Islamic notions of the frontier can become intertwined with evolutionist/ developmentalist ideas. As we will see, one does not have to go too far to the west to encounter such discourses.

\section{'As far as Papua' - Al-Khairaat's frontier and the light of the Prophet}

When I did research about eastern Indonesia's biggest Islamic organisation, called Al-Khairaat, which is particularly strong in central and northern Sulawesi and to a certain extent also in the northern Moluccas, 'Papua' frequently popped up in my conversations, i.e. when my interlocutors referred to the high mobility of the organisation's founding father. Al-Khairaat was established in Palu, Central Sulawesi, by Sayyid Idrus Al-Jufri, who was born in the Hadhramaut. In 1925, at the age 36, he migrated to the then Netherlands East Indies. After moving from place to place along the networks of the Hadhrami diaspora in Java and eastern Indonesia, in 1930 he finally settled in Palu where he established the Madrasah Al-Khairaat. Nevertheless, Sayyid Idrus' life was still characterised by a high degree of mobility. He began to build his translocal networks within north-eastern Indonesia by inviting young boys of Hadhrami or local descent to accompany him back to Palu, giving them the opportunity to enroll in the Al-Khairaat school (Azra 2000). These graduates of Al-Khairaat contributed considerably to the spread of the organisation by opening schools in their hometowns modelled after the Palu example. What also informed Sayyid Idrus' popularity was his noble ancestry, since his genealogy goes back to the Prophet Muhammad, which is also indicated by bearing the title sayyid (Slama 2011). 
Among Al-Khairaat members, the journeys of Sayyid Idrus are considered legendary. I was told that Sayyid Idrus explored villages so remote that no AlKhairaat member ever visited them again. In these narratives Papua is mentioned frequently. In order to emphasise the achievements of Sayyid Idrus Al-Khairaat members like to employ the phrase that he went 'as far as Papua' (sampai di Papua) or 'as far as Irian' (as Papua was called until the end of Suharto's reign). They also like to point out that Al-Khairaat currently runs two branches in Papua, one near Jayapura and one close to Manokwari.

In my conversations with Muslims active in Al-Khairaat we discussed why Sayyid Idrus established his organisation in this remote eastern Indonesian region. It was $\mathrm{Ibu}^{8}$ Achmisah, the vice chairwoman of the women's division of Al-Khairaat, Wanita Islam Al-Khairaat, who explained that before Sayyid Idrus' arrival the people in Palu 'had no religion' (tidak punya agama). Her friend, also an active member of Wanita Islam Al-Khairaat, added that back then 'there was still jahiliyyah time' (masih ada jaman jahiliyyahnya). 'Yes there was,' the vice chairwoman continued, 'well, there was already Islam, but there was no implementation of the sharia. People were drunk, they gambled. But then Sayyid Idrus settled [in Palu] ... Thank God! From there he spread his wings as far as Irian, as far as Ternate, Ambon, and North Sulawesi. ${ }^{9}$ These accounts by Al-Khairaat members portray the efforts of Sayyid Idrus and his organisation as an attempt to push back the frontier in space and time. Highly mobile ways of proselytising and the opening of Islamic schools in remote areas are aimed at incorporating new territories, eastern Indonesia and especially Papua, into the Dar al-Islam, simultaneously leaving behind the jahiliyyah. In contrast to the accounts by Hadhramis from the Moluccas, who have direct kin and trade relations with Papuans, the discourses I encountered in Sulawesi feature a particular spatial hierarchy with Papua on its furthest and, consequently, lowest end.

Yet, similar to the Moluccas, on Sulawesi one can also find discourses that highlight marriage as a legitimate way to make the Papuan frontier more Islamic. One of my interlocutors, Pak Husein, also a sayyid and active Al-Khairaat member, recalled a distant relative of his who had migrated to Papua. He told me that the Prophet Muhammad himself married a woman of dark skin, a rich, 60-year-old widow of high influence, with the motive that the people would follow her in becoming Muslims, which they eventually did. He further pointed out: 'Just like the Prophet we like the Irian people in order that they can become Muslims faster.'10 And he reminded me: 'The Prophet said that wherever his descendants will live, God willing, there will be light. That means that we don't have to worry in the jungle of Irian. As long as we behave properly, God

8 In Indonesian 'Ibu', literally 'mother', is a respectful form of address for married women.

9 Interview in Palu, Central Sulawesi, 8 December 2007.

10 Interview in Tondano, North Sulawesi, 13 April 2008. 
willing, there will be light.' ${ }^{11}$ By employing the Sufi concept of 'the light of the Prophet' that is said to be handed down from generation to generation among his descendants, Hadhramis can, in this view, even illuminate what is imagined as the dark jungle of Papua. Equating Papua with the jungle and darkness, including dark skin, alludes to the jahiliyyah in pre-Islamic Arabia that has been enlightened by the Prophet and, when transferred to other times and places, can have similar effects. Dark jungle and dark skin also evokes Western evolutionist concepts in which the jungle stands for wilderness, where only people of the lowest level of human development live, such as the ostensible Papuan stoneagers. ${ }^{12}$ However, the primary concern of Hadhramis from eastern Indonesia is not to advance Papuans' standard of living in a developmentalist fashion, but to marry them and teach them proper behaviour according to Islamic law. In Papua, overcoming the jahiliyyah thus means to overcome the darkness of the jungle through prophetic radiance. Although they are deeply entrenched in Islamic theology, these accounts indicate at least a partial convergence of Islamic and evolutionist-cum-developmentalist notions of the frontier where 'the jungle' and the jahiliyyah show semantic affinities and where Papua is seen as the furthest-cum-wildest territory that can be reached by Indonesian Hadhramis.

Moving further west to Indonesia's capital Jakarta, but remaining within the networks of the Hadhrami diaspora, reveals further insights into Islamic notions of the Papuan frontier. Such a step evinces aspects of spatio-temporal hierarchisations that again point to entanglements of Islamic and evolutionist/ developmentalist notions of the frontier, albeit not in the same variations we have encountered so far.

\section{‘No signal': A Jakartan preacher's frontier}

In post-Suharto Indonesia, other bearers of the light of the Prophet discovered Papua, most notably Habib ${ }^{13}$ Munzir Al-Musawa, a Hadhrami sayyid and founder of the Majelis Rasulullah, which is the biggest prayer association in Indonesia's capital, attracting thousands of Muslims to their regular meetings. After the breakdown of the communist regime in South Yemen in 1989, Habib Munzir belonged to the first group of young Indonesian Hadhramis who were given the opportunity to study in the Hadhramaut. He went to the, at that time,

11 ibid.

12 In Indonesia, with regard to the ambiguous zone of the forest, evolutionist perceptions resonate with and have probably reinforced indigenous ones; e.g. Dove (1985: 19) asserts for Java: 'Just as cleared land became associated with the rise of the Javanese states and their cultures, so too did the forest come to be associated with uncivilized, uncontrollable, and fearful forces.'

13 'Habib' (literally 'the beloved') is a form of address for descendants of the Prophet Muhammad popular among Hadhramis and their followers. 
newly founded and, in the meantime, famous Darul Mustafa boarding school run by Habib Umar bin Hafiz bin Sheikh Abubakar, the leading Sufi figure in the Hadhramaut who is also very popular among diaspora Hadhramis (Alatas 2010). Habib Munzir married a woman from the Hadhramaut, also of Hadhrami sada descent, and brought her to Indonesia where she started to preach among women in Jakarta (Nisa 2012). Most importantly in the context of this chapter, Habib Munzir visited Papua several times, in 2007, 2008 and 2010. All his journeys were covered by the popular bi-weekly Islamic magazine Al-Kisah, which is also owned by a Hadhrami sayyid. ${ }^{14}$ The articles feature diary entries of Habib Munzir as well as direct quotations of what he said with the effect that the reader feels informed about how Habib Munzir personally experienced Papua through his diasporic Hadhrami and at the same time Indonesian-Jakartan eyes.

Habib Munzir set foot in Papua for the first time on 9 May 2007 in Manokwari where he was welcomed by Ahmad Baihaqi, a preacher and Majelis Rasulullah activist from Jakarta who had expanded his activities to Papua. He was brought to the 'only Muslim hotel in Manokwari', as Habib Munzir laments in his diary, published by Al-Kisah shortly after his visit. In the evening he preached at the mosque of the Indonesian navy where a maulid, a ritual celebrating the birth of the Prophet Muhammad, was staged. Around 700 Muslims attended the event, which Habib Munzir found remarkable for such a 'remote town' (kota terpencil). The next day, Habib Munzir learned about the difficulties Muslims in Manokwari face if they want to build a mosque, although in Habib Munzir's perception the ratio between Muslims and Christians is already 'fifty-fifty' (English in original). Alluding to the so-called perda injil, or Christian by-laws, drafts of which had been discussed in Manokwari prior to Habib Munzir's visit, he expressed his hope that in the future female Muslims could continue to freely wear the veil. ${ }^{15}$

On that second day of his visit, Habib Munzir travelled to an Islamic boarding school located about 65 kilometres outside Manokwari where he found it difficult to find a signal for his mobile phone or to connect his laptop to the internet. This is illustrated with a picture of Habib Munzir sitting on the floor with his laptop put in front of him, holding his mobile phone in his left hand. The caption of this picture reads: 'Habib Munzir Al-Musawa opens his laptop. There is no signal.' From the boarding school, he continued his journey to a 'very remote Muslim area' (wilayah Muslim yang sangat terpencil). When they returned to Manokwari in the night, 'the street was very dark and quiet' (jalanan gelap dan

14 See: Al-Kisah No. 12/4 - 17 Juni 2007, 50-53; Al-Kisah No. 23/3 - 16 Nov. 2008, 38-46; Al-Kisah No. 04/22 Feb - 7 Maret 2010, 52-55; Al-Kisah No. 05/8 - 21 Maret 2010, 70-71; Al-Kisah No. 06/22 Maret - 4 April 2010, 50-53.

15 Al-Kisah No. 12/4- 17 Juni 2007, 50-51. Similar to the so-called perda syariah in other parts of Indonesia, these by-laws have potentially discriminating consequences for those who do not belong to the local religious majority. The draft of the Manokwari by-laws has been heatedly discussed in Papua and in Indonesia at large (ICG 2008). See also the chapters of Myrttinen and Timmer in this volume. 
sepi) and Habib Munzir asked his local companions whether this area would be dangerous at night. They explained that the 'Irianese' do not go out after sunset because they believe in a witch that kills people and eats their entrails at night. In consideration of the fact that his journey went according to plan, Habib Munzir expressed his gratitude to his local followers who guarded him and slept in front of his room at night. On the third day, Habib Munzir flew back to Jakarta. ${ }^{16}$

Habib Munzir's second trip in October 2008 also brought him to Manokwari. But this time he travelled further away from the city, "penetrating the interior of Papua' (menembus pedalaman Papua), as the title of the story in Al-Kisah reads, suggesting that Habib Munzir is exploring the real frontier, 'the interior', where he 'has to fight to advance on the muddy roads in the thick jungle' (berjuang menembus jalan berlumpur di tengah hutan lebat). The readers of Al-Kisah further learn that Habib Munzir went into the interior to introduce the Islamic confession of faith and that he proselytises not only in 'comfortable areas' (daerah yang nyaman) but 'reaches all corners' (hingga seluruh pelosok). This narrative is supported by a picture on the first page of the Al-Kisah article depicting Habib Munzir in his long white Arab dress and white turban among Papuans in partly traditional attire with their chests naked, some of them holding bows and arrows. Upon his arrival in Manokwari, he was again welcomed by Ahmad Baihaqi. Ransiki, located about 100 kilometres south of Manokwari, was the first destination of their trip. Baihaqi has good relations to the place since from there he brought young Papuan Muslims to Jakarta to teach them Islam. On the way, Habib Munzir 'was more crying than he was speaking' (lebih banyak menangis daripada bicara) because during the three-hour journey he could not spot any Muslims. Instead, he saw 'huge religious buildings of adherents of another religion' (bangunan besar tempat ibadah penganut agama lain). Only shortly before Ransiki did he see young men on motorbikes waving the flag of the Majelis Rasulullah, some of them 'indigenous people' (penduduk asli), wearing the jackets of the Majelis Rasulullah. He could hardly believe what he saw: Papuan Muslims wearing the peci putih (a white cap identified with Islam in Indonesia) and waving the flag of the Majelis Rasulullah in this 'remote area' (wilayah terpencil). After Habib Munzir addressed the Muslims of Ransiki, they continued their journey to Bintuni. ${ }^{17}$

On their long way to Bintuni, road conditions deteriorated. The Land Cruiser rented by Habib Munzir's group could hardly get through the mud that is '50cm or more' deep. These road conditions and the 'wild' environment are also illustrated by pictures of which the captions read: 'The car is stuck in the mud. The struggle to proselytise penetrates the interior' (Mobil terperosok

16 Al-Kisah No. 12/4 - 17 Juni 2007, 52-53.

17 Al-Kisah No. 23/3 - 16 Nov. 2008, 38-41. 
dalam lumpur. Perjuangan dakwah menembus pedalaman) and 'Prayer in the middle of the jungle' (Shalat di tengah rimba). At half-past eight in the evening Habib Munzir arrived in Bintuni and checked in at 'the only hotel in the town of Bintuni that has air conditioning' (satu-satunya hotel di kota Bintuni yang dilengkapi $A C$ ). The next morning, 'hundreds of Muslims' were awaiting Habib Munzir in front of the hotel. Some of them were moved to tears, and explained that they only heard about habib from their grandfathers and that Habib Munzir's visit is the first one of a habib in 'hundreds of years'. Local figures also emphasised that Islam came to Bintuni in the 16th century but then disappeared. In the mosque a maulid was celebrated after which Habib Munzir addressed the Muslims. For lunch Habib Munzir asked for local food and was served papeda (porridge made of sago flour) with fish. Back in the hotel Habib Munzir had a meeting with local Muslim figures who told him of a village 'close to the beach' where an old copy of the Qur'an was found and the population 'is Muslim, but they don't know Islam, they don't know the confession of faith anymore. They only know that they are not allowed to eat pork. They think that this is traditional law, whereas this is Islamic law' ${ }^{18}$ The locals thus asked him: 'Where are the preachers from Jakarta? How can we know and learn Islam? Where are the rich people of Jakarta? They send a lot of money to Palestine, Bosnia, Afghanistan, but they forget us, whereas we are Muslims of the same nation as they are, the inhabitants of Jakarta.' ${ }^{19}$

On the way back to Manokwari the road conditions were even worse than the day before and the Land Cruiser had to be freed from the 'claws of the mud' (cengkeraman lumpur). On the way they met the father of one of Ahmad Baihaqi's students who 'still follows another religion, but apparently is beginning to show interest in becoming a Muslim' (masih beragama lain, tapi kelihatannya sudah mulai tertarik masuk Islam). They also passed a small mosque (mushalla) that was funded by 'a businesswoman from Jakarta' who once visited the area in the course of her trade activities. Then Habib Munzir fell asleep and dreamt of a young habib who told him that he had proselytised here but had died as a martyr. Habib Munzir felt pity for the young habib whose 'grave in the jungle of Irian Jaya nobody knows' (kuburanya tak dikenali orang di dalam

\footnotetext{
18 Al-Kisah No. 23/3 - 16 Nov. 2008, 44: ‘Mereka muslim tapi tak tahu agama Islam, mereka sudah tidak kenal syahadat. Mereka hanya mengenal satu ajaran, yaitu tak boleh makan babi. Mereka menanggap itu hukum adat, padahal itu hukum Islam.'

19 ibid.: 'Di mana dai-dai dari Jakarta? Lalu dari mana kami akan mengenal dan belajar Islam? Di mana para hartawan dari Jakarta? Para hartawan di Jakarta mengirim dana uang banyak ke Palestina, Bosnia, Afghanistan, tapi melupakan kami ... padahal kami muslimin saudara sebangsa dengan mereka, penduduk Jakarta.' This can be read as a Muslim Papuan variety of what Stasch calls (in this volume) 'strategies of selflowering as a way to elicit relations' in the context of the Korowai.
} 
rimba belantaran Irian Jaya), and he was thinking of leaving Jakarta for Papua to proselytise there, perhaps meeting a similar fate as the young habib of his dream. Nevertheless, the next day he flew back to Indonesia's capital. ${ }^{20}$

The third trip of Habib Munzir to Papua in January 2010 was covered by AlKisah in three subsequent issues. This time he flew not to Manokwari but to Sorong where Ahmad Baihaqi awaited him. They visited a member of the local parliament, whose father and grandfather built mosques in Sorong. They lamented the current situation that the majority of members of parliament are Christians although Sorong's population shows a Muslim majority. They then left for Teminabuan, about 200 kilometres southeast of Sorong, with a 'Mitsubishi Ranger $4 \times 4^{\prime}$ '. On the way they met no Muslims. Instead, they saw only 'nonMuslim villages' with their 'grand religious buildings'. Under the subheading 'The Beauty of Tolerance' (Indahnya Toleransi) the story continues with the appearance of a Catholic nun who asked to hitch a ride to Teminabuan. Habib Munzir allowed her to go with them and the nun sat down on the open loading space at the rear of their car. After a while it started to rain which caused Habib Munzir to salute the nun for her fortitude. At the same time he felt ashamed because he was sitting comfortably inside the car. Consequently, he stopped the car and invited the nun to change positions. Sitting in the rain at the back of the car, Habib Munzir began to reflect about his celebrity life in Indonesia's capital, talking to himself: 'You get spoiled in Jakarta. Thousands of people contend to kiss your hand. They glorify and flatter you. Your struggle of proselytisation is only limited to going up and down the stage while being glorified and flattered. Now you deserve to feel proselytisation like this. This is the field for a preacher of the way of Allah. You are too spoiled. You also have to feel proselytisation like this ... Feel the deliciousness of proselytisation, keep sitting here and bear it, oh Munzir you sinner, idler, and spoiled man! ${ }^{21}$

When they arrived in Teminabuan, Habib Munzir checked in at a 'basic hotel but already equipped with air conditioning' (hotel sederhana tapi sudah dilengkapi $A C)$. Then he paid the driver and showed him on the screen of his smartphone an event of his Majelis Rasulullah at the Monas (national monument) in Jakarta. The driver was impressed by the 'hundreds of thousands' of participants and could hardly believe that the man who led this event stood in front of him. ${ }^{22}$ The next morning Habib Munzir rented a boat leaving for Kokoda, located on the south coast of the Bird's Head Peninsula. On the way to Kokoda, Habib Munzir

20 Al-Kisah No. 23/3 - 16 Nov. 2008, 44-46.

21 Al-Kisah No. 04/22 Feb - 7 Maret 2010, 55: ‘Kau di Jakarta dimanjakan. Ribuan orang berebutan ingin mencium tanganmu. Kau dimuliakan dan disanjung. Perjuangan dakwahmu hanya sebatas naik-turun mimbar dalam kemuliaan dan sanjungan. Sekarang patut kau rasakan dakwah yang seperti ini. Inilah medan seorang dai penyeru ke jalan Allah. Kau terlalu dimanjakan. Kau harus merasakan juga dakwah yang seperti ini ... Rasakan lezatnya dakwah, tetaplah duduk di tempat itu dan bertahan, wahai Munzir pendosa, pemalas, dan manja!'

22 Al-Kisah No. 05/8 - 21 Maret 2010, 70-71. 
contemplated 'this remote area. Telephone is not yet available, electricity only in Teminabuan and that only at night. There are no Islamic religious teachers or schools in Teminabuan ... [but] strong waves of non-Islamic proselytisation and non-Islamic schools' ${ }^{23}$ Kokoda is introduced as 'the third Islamic region [of Papua] that has been penetrated by Islamic scholars from the Hadhramaut' (wilayah muslim ketiga yang dimasuki ulama Hadhramaut) with Fakfak and Babo being mentioned as the other two regions. Hadhramis are credited with building the Masjid Annur, the mosque of the light, in Kokoda, alluding to the light of the Prophet Muhammad. In the article it is said that they stated: 'We ignited the light in Kokoda' (Kami Taruhkan Cahaya di Kokoda). But after this initial influence from the Hadhrami descendants of the Prophet Muhammad, the area 'was not contacted anymore' (tidak disentuh lagi). This is the reason why the five daily prayers were increasingly not practiced and people only gathered for the Friday prayer. Religious life was only revived by Habib Munzir's companion Ahmad Baihaqi, who had visited Kokoda and brought some young men back to Jakarta to study Islam. So when Habib Munzir arrived in Kokoda, he could see the flag of the Majelis Rasulullah. They stayed in a house that was 'good enough for Kokoda standards, but without electricity, no mobile phone signal, let alone telephone' (cukup bagus untuk ukuran Kokoda, tapi tidak ada listrik, tidak ada sinyal handphone, apalagi telepon). After the evening prayer, Habib Munzir gave a sermon at the Masjid Annur, when 'many Muslims prayed for the first time, although they were already old' (banyak orang Muslim yang baru pertama kali shalat, walau mereka sudah lanjut usia). When Habib Munzir gave his sermon, the Muslims of Kokoda were 'moved to tears'. After the gathering was over, 'their tears were still running down their cheeks. They were contending to greet me, as it happens in Jakarta' ${ }^{24}$ With this emotional account the last of the articles in Al-Kisah ends.

Habib Munzir's engagement in Papua was well-recognised among Majelis Rasulullah members, as it was published not only in Al-Kisah but also on the organisation's website ${ }^{25}$ and on YouTube where one can watch shorter videos of his journeys. ${ }^{26}$ When Habib Munzir passed away on 15 September 2013 in Jakarta, just having turned 40, his followers came from many places in Indonesia to pay their last respects. Interviewed by Indonesia's popular news portal detik. com, a Majelis Rasulullah member from Banjarmasin, South Kalimantan, stated

23 Al-Kisah No. 06/22 Maret - 4 April 2010, 51: ‘... wilayah yang terpencil ini. Telepon belum masuk, listrik baru di Teminabuan, dan itu pun hanya pada malam hari. Pengajar, seperti ulama, atau pesantren tidak ada di Teminabuan ... [tapi] hempasan kekuatan dakwah agama non-muslim dan sekolah-sekolah non-muslim.' 24 Al-Kisah No. 06/22 Maret - 4 April 2010, 53: '... air mata masih mengalir di wajah mereka. Mereka berebutan untuk bersalaman dengan saya, sebagaimana juga terjadi di Jakarta.'

25 http://www.majelisrasulullah.org/. See also Warta (2011: 325-329) who interprets the web coverage of Habib Munzir's Papua tours as an Islamic answer to the Christian discourse that depicts Manokwari as 'gospel city'.

26 e.g. see 'Habib Munzir di Manokwari Papua': http://www.youtube.com/watch?v=ZSrysiZ8c_c (accessed 16/09/2013). 
proudly that 'friends from Surabaya will come, from Tegal, Sumatra, and also from Papua ... He [Habib Munzir] even had students from Papua. He taught them until they were mature, and then sent them back to Papua to proselytise' ${ }^{27}$

Let me start my discussion of Habib Munzir's account of Papua by contrasting it with the narratives of the eastern Indonesian Al-Khairaat members. Although post-Suharto eastern Indonesia has seen horrible violence along religious lines in Poso (Central Sulawesi) and the Moluccas, Al-Khairaat members who live in provinces with a strong Christian presence are less concerned with Christian activities in Papua than Habib Munzir who, coming from a part of Indonesia with a clear Islamic majority, seems to be shocked by assertions of Christian identity in the places he visited. So, for Habib Munzir, Papua is first of all a land where it can happen that one has to stay in the 'only Muslim hotel', where it can be difficult to build mosques, where one encounters 'huge religious buildings' that are not Islamic and where one can travel for hours without spotting any Muslims. By contrast, the Al-Khairaat members I interviewed, who had never travelled to Papua, one must add, imagine Papua as a place that has the potential to leave behind the jahiliyyah and become part of the 'house of Islam' such as other parts of eastern Indonesia. They consider the region where they live to be part of an Islamic frontier with Papua as its remotest and 'wildest' extension where 'the jungle' and 'the primitiveness' of its inhabitants are the greatest obstacles to proselytisation, whereas Habib Munzir's account rests upon a clear dichotomy between centre and periphery, i.e. between Jakarta and Papua, finding its expression in a discourse that is composed of worries about Christian dominance as well as of Hadhrami diasporic and evolutionist/developmentalist perspectives.

Unsurprisingly, the Hadhrami diasporic perspective can be found in the accounts of both the eastern Indonesian Al-Khairaat members and the Jakartan preacher. Both evoke 'the light of the Prophet' that can illuminate the Papuan frontier. Habib Munzir clearly positions himself in a tradition of Hadhrami proselytisation in Papua, as he visits places where Hadhramis are said to have been before and to have left traces, such as the mosque in Kokoda. He even dreams of a Hadhrami who once proselytised in the region and was killed, bemoaning that his grave 'in the jungle' is unknown. This remark must be understood against the backdrop that, as mentioned earlier, graves represent significant sites in the Hadhrami diaspora and grave visits are an important part of Hadhrami religious practice. Habib Munzir thus saw himself on a mission akin to the missions of Hadhramis of former times - such as Sayyid Idrus Al-Jufri, the tireless traveller and founder of Al-Khairaat, one might add - converting locals to Islam or teaching local Muslims how to practice their religion properly.

27 http://news.detik.com/read/2013/09/16/005955/2359319/10/pelayat-dari-berbagai-daerah-padatirumah-duka-habib-munzir (accessed 16/09/2013). 
Despite these similarities, the theme of preaching in 'the jungle' features stronger in Habib Munzir's Al-Kisah report than in the accounts of eastern Indonesian Hadhramis, suggesting that as an inhabitant of Indonesia's capital he is more influenced by evolutionist-cum-developmentalist discourses. Apart from the notion of the jungle being part of the semantic field of evolutionist discourses about primitivism and the stone-age (see Stasch's chapter) that he shares with the Al-Khairaat Hadhramis, Habib Munzir's account has a stronger developmentalist emphasis. In fact, he likes to highlight the technological differences between life in 'high-tech' Jakarta and 'underdeveloped' Papua. The reader is thus informed that the hotel where he stayed was basic but 'equipped with air conditioning', if electricity was available and if it was, at which times of day or night. The reader is also informed about road conditions and, most importantly, about the (im) possibility of real-time communication, as it is conveyed to the reader exactly where on his journeys there was 'no signal'. Inspired by Danilyn Rutherford's chapter (in this volume), one can read Habib Munzir's journeys also comprising technology demonstrations, not to demonstrate the stone-age per se as Dutch colonial officials would have done, but to emphasise the differences between 'real-time' Jakarta and 'backward' Papua. Habib Munzir travelled with his laptop and his smartphone, which he also employed to show Muslims in Papua videos demonstrating how he can mobilise the masses in the capital, i.e. how Islam can thrive in a developed and connected place.

Yet the conditions in Papua perceived as deficiencies in both fields, technology and religion, were psychologically straining for Habib Munzir. His encounter with the brave old Catholic nun led to self-criticism of being a spoiled Jakartan who for the first time experiences proselytisation in such an environment, which he perceives as being more authentic than his activities in Jakarta. Papua, not Jakarta, is 'the field for a preacher of the way of Allah'.$^{28}$ Moreover, his account comprises not only self-criticism but also accusations of the state of Islamic proselytisation in Indonesia that leaves large parts of Papua abandoned. This is clearly addressed to the readership of Al-Kisah, which is mainly based on Java. Papua is thus portrayed as a region that is not only in need of material but also spiritual development, where people long for receiving money and preachers from Jakarta and like to remind visitors that 'we are Muslims of the same nation'. Thus, enlarging 'the house of Islam' and overcoming the jahiliyyah by inflaming 'the light of the Prophet' goes hand in hand with developmentalist agendas of making Papua part of the real-time. In Habib Munzir's account, frontier discourses of various kinds overlap and merge as they are informed by

28 In fact, among Indonesian Christian preachers one can encounter similar discourses, as they see working in Papua as both, in most need of their efforts but also as a personal/spiritual trial (Jenny Munro, personal communication). 
From 'Stone-Age' to 'Real-Time'

themes prevalent in Islamic and secular imaginaries of peripheral regions. It is in the conclusion of this chapter where I will come back to the spatio-temporal hierarchies intrinsic to his account.

\section{Hadhramis as Papuans and alternative Papuan imaginaries}

In this chapter so far, we followed Indonesian Hadhramis from eastern Indonesia and Java in how they perceive and experience Papua as a frontier region. This discussion would be incomplete, however, if we did not consider those Hadhramis with a longer history in Papua, since the views from Jakarta and parts of eastern Indonesia differ greatly from the views from within Papua, where we can observe today a Muslim Papuan identity in the making as well as alternative Islamic practices and imaginaries.

As outlined above, Arab migration to Papua resulted in trade, intermarriage and the settlement of Hadhramis in the region. For example, a high degree of integration into local society can be observed among Hadhramis in the Raja Ampat islands. Albert Remijsen (2002: 180) writes in his dissertation about clans of non-Raja Ampat origin that have become part of the Ma'ya, as the Muslim population of the islands is called: 'These clans speak Ma'ya and are totally integrated in Ma'ya society.' And among them, Remijsen cites the Alhamid, mentioned previously as one of the major Hadhrami families in the region. In Sorong I was able to interview a representative of this Hadhrami family, Basri Alhamid, the headmaster of Sorong's State Islamic Senior High School (Madrasah Aliyah Negeri) who was born in 1956 on Salawati, one of the Raja Ampat islands. He was quite surprised when I asked him about his Arab descent, as he identifies more with the land where he was born: 'My mother was still of Arab descent, and my father, too. But the mother of my mother was of Raja Ampat origin ... and we were born here, grew up here and became Papuans. If I'm called an Arab, it's perhaps just the family name ... In Fakfak many Arabs married Papuans. This is a mixing of many layers so that sometimes you can see that they are Arab and sometimes you can't see it anymore ... Like me, you can't see that I'm Arab.' ${ }^{29}$

Close identifications with the land where one was born and currently lives are actually nothing special among Hadhramis, as they like to quote the hadith, i.e. the saying of the Prophet Muhammad, that reads, 'The love of the fatherland stems from faith' (in Arabic, 'hubb al-watan min al-iman'). For Hadhramis, stressing one's loyalty to Indonesia was particularly important in late colonial

29 Interview in Sorong, West Papua, 23 April 2008. 
times and after Indonesia's independence when their status as citizens of the new republic was at stake (Jonge 2004). It seems that in post-Suharto, Special Autonomy Papua, in which nationalist and Christian discourses increasingly converge (see chapters by Timmer, Myrttinen, and Richards in this volume), Hadhramis as Muslims are in a familiar situation of having to prove that they are with, and actually part of, the indigenous population.

Given the distinct tendency of Hadhramis in the Moluccan-Papuan region and in Indonesia at large to occupy leading positions in Islamic matters, it does not come as a surprise that Papuan Hadhramis were involved in establishing an organisation for Papuan Muslims in post-Suharto Indonesia, the Papuan Muslim Council or Majelis Muslim Papua (MMP). The MMP was formed in 2007 and grew out of the Solidaritas Muslim Papua organisation which was founded in 1999 by 47 Muslim figures, including Thaha Alhamid and Sayyid Fadhal Alhamid who are of Hadhrami descent. Thaha Alhamid is a particularly salient figure since he is part of the Papuan nationalist elite, and perhaps the most prominent Muslim Papuan nationalist, serving as the secretary general of the Papua Presidium Council or Presidium Dewan Papua (PDP) (Pamungkas 2011: 139, 141; Wanggai 2008: 199-200). According to Cahyo Pamungkas (2008, 2011 : 140) the MMP was established in order 'to counter the proposition that Islam is identical with Indonesia', to build a 'communication bridge between Muslim immigrants and Christian Papuan society', to advocate indigenous Papuan rights, human rights and to combat economic inequality, and to counter the influence of Indonesian Islamic organisations that usually focus on Muslim migrants. Its role in bridging interests between Christian and Islamic camps was tested in 2007 in the course of the establishment of the State Islamic Institute Al-Fatah or Sekolah Tinggi Agama Islam Negeri (STAIN) Al-Fatah in Jayapura. STAIN Al-Fatah was protested by the Indonesian Priest Association (Asosiasi Pendeta Indonesia) and other groups, and it was Thaha Alhamid who was heavily involved in solving the dispute by convincing the Christian governor of Papua that Papuans will also benefit from the institute (ibid. 147-148). The institute is now headed by another member of the Alhamid family, namely Idrus Al-Hamid, who is a close observer of Christian-Muslim tensions in Papua (Al-Hamid 2013, 2014).

Despite this high level of integration into Papuan Muslim circles and their leading roles in Islamic organisations and institutions, Special Autonomy Papua can haunt Papuan Hadhramis in ways that previously would have been unthinkable. Consider the case of Mohammad Musa'ad, who was one of the negotiators on the Special Autonomy policy, but was rejected as a vice-governor candidate in 2005 because of his Arab ancestry (Pamungkas 2011: 133, 143). The International Crisis Group (2006: 8) also recognised his case: 'Although Musa'ad's mother is a Papuan from FakFak, his father is of Arab descent.' According to 
the Papuan People's Council (Majelis Rakyat Papua, MRP), the body that has the right to screen candidates according to Special Autonomy legislation, 'an indigenous Papuan is a person of the Melanesian race, whose mother and father are Papuan, with patrilineal heritage, and who has a cultural base with a local language, a Papuan tribe, a village to which he or she belong, and a customary tradition (adat istiadat)' (ibid.). However, there is also the possibility that one can become a candidate if $\mathrm{s} / \mathrm{he}$ is 'accepted and acknowledged as an indigenous Papuan by the local customary community' (ibid.: 9), and Mohammad Musa'ad had the support of the Bombarari tribe in the Fakfak region. Yet he was still rejected since, as one member of the MRP explained to the ICG, many MRP members prefer 'full-blooded Papuans, with black skin and frizzy hair' (ibid.) (see also Wanggai 2008: 206).

Despite this trend towards rigid views of who is to be considered a Papuan, Hadhramis with a Papuan background often consider themselves (also) as Papuans and see Papua as the centre of their religious and political activities. They do not share the perspectives of their fellow Hadhramis in other parts of Indonesia that are imbued with Islamic and secular frontier notions. Moreover, as Muslims who have resided in Papua for several generations they not only embody Hadhrami strategies of becoming local, such as intermarrying and identifying strongly with the land where one was born, but are also familiar with interpretations of Islam that follow the logics of Papuan mythology.

These interpretations are particularly widespread in the Bird's Head and Bomberai peninsulas and basically say that Islam, like Christianity, is indigenous to Papua: Papua is the land where Adam and Eve descended, where Noah's ark was stranded, and where all subsequent figures of the holy books lived. A mountain on the land between Arguni Bay and Wondama Bay is known under the name of 'mountain of the prophet' (gunung nabi) and some Papuan Muslims like to perform the pilgrimage there instead of travelling to Mecca (Wanggai 2008: 59-60). As an example for such oral traditions I want to refer to a myth that comprises a story of two springs being located close to Fakfak. One is a salt water and the other a sweet water spring. Both are guarded by men who owned books. The guard of the salt water spring owned the Qur'an, whereas the guard of the sweet water spring the Bible. The teachings from the salt water spring were then adopted by the people living on the coast and teachings from the sweet water spring found a following among the people living in the interior, alluding to the distribution of Muslims and Christians in the region (Onim 2006: 53-54; Warta 2011: 334). These narratives are reminiscent of Papuan cosmology, such as Koreri, that identifies Jesus Christ as Papuan (Rutherford 2003, 2012), and denies any portrayal of Papua as an Islamic frontier zone or as an underdeveloped periphery, let alone as the residue of a stone-age. Rather, Papua 
appears as the centre of all Abrahamic religions, including Islam, wherefrom today's civilizations emanated (see also the chapters by Myrttinen and Timmer in this volume).

\section{Concluding remarks}

This chapter has embarked on frontier concepts that rely heavily on evolutionist and developmentalist discourses as they have been - and still are - directed towards Papua and its indigenous inhabitants. These discourses express particular spatio-temporal hierarchisations characterised by a logic of stages of human and societal development, with Papua and Papuans being relegated to the lowest level. As such, it has to be emphasised, they differ from Islamic frontier concepts of the Dar al-Islam/Dar al-Harb and the jahiliyyah which rest upon a dichotomy between an Islamic and a non-Islamic order. These Islamic frontier concepts do not provide for treating non-Islamic societies unequally by imposing different degrees of devaluation. As a society can be more or less 'primitive', or more or less 'underdeveloped', it cannot be more or less 'un-Islamic', as it is part of the 'house of Islam' or it is not. Enlarging the Dar alIslam and overcoming the jahiliyyah is thus the primary goal that can be applied to every community and every human being, including Papuans. And from a Hadhrami diasporic perspective there are different, but combinable, ways to accomplish this, i.e. through trade, proselytisation and marriage.

However, these ideal types (in a Weberian sense) of Islamic frontier concepts can hardly be discerned as such in the narratives of Hadhramis from Sulawesi and Jakarta. Members of Al-Khairaat see themselves situated in a frontier zone of which Papua is its remotest part. Whereas in the Islamic parts of central and northern Sulawesi the jahiliyyah has been overcome due to the efforts of the exemplary preacher Sayyid Idrus Al-Jufri, in Papua the bearers of 'the light of the Prophet' still meet the jungle where darkness, and dark-skinned people, prevail. In the strongholds of Al-Khairaat on Sulawesi the jahiliyyah has been left behind for several generations now, while remote Papua lags behind these developments. We see here how spatio-temporal hierarchisations that are reminiscent of evolutionist-cum-developmentalist frontier notions inform Islamic depictions of the frontier assigning Papua a particularly lowered place.

Such developmentalist inflections of Islamic frontier concepts can also be discerned in the account of the Jakartan preacher Habib Munzir Al-Musawa, another bearer of 'the light of the Prophet', in which they feature even more strongly. In his account, the Papuan 'jungle' lacks not only proper Islamic proselytisation but also the amenities of the contemporary age, such as good roads, nice hotels, electricity and especially real-time communication. The reader 
learns about the dominance of Christianity, Muslims who have forgotten how to pray properly, and at the same time, where and when electricity does not work or is not available and mobile communication is not possible due to the lack of signal. Habib Munzir was a bearer of 'the light of the Prophet' who wanted to see Papua being illuminated not only by prophetic radiance but also by the data streams of modern communications. His account suggests that remote Papua lags behind because it is not part of real-time communication circles and of Islamic real-time Indonesia at large. It is even a place where Muslims can be forgotten, where no preachers from Jakarta want to go, and which seems to be farther away than places outside Indonesia such as Palestine.

This stronger emphasis on nationalist-developmentalist themes in Habib Munzir's account, compared to the views of Hadhramis from Sulawesi, corresponds with actual geographic distances and all the more so with an innerIndonesian centre-periphery hierarchy with Jakarta featuring as the apex of the nation. The (symbolically) closer to the centre the beholder is based, it seems, the more pronounced these nationalist-developmentalist views become and the stronger spatio-temporal hierarchies intrinsic to them inform Islamic frontier notions. Having organised huge prayer meetings at Jakarta's central Monas square, the memory of which he carried with him in digital form on his smart phone, Habib Munzir epitomises the nation's centre, whereas the Hadhramis from Sulawesi live in distance from both Jakarta, the exemplary centre, and Papua, the ultimate frontier.

However, as this chapter also attempts to demonstrate, these frontier notions with their multiple ways of spatio-temporal hierarchisation are not all-pervasive and dominant. In fact, Papuan Muslims, including Hadhramis with a Papuan background, began to challenge discourses that treat Papuan Muslims as mere objects of Islamic and national development. The establishment of the Papuan Muslim Council, in which Hadhramis were heavily involved, provided Papuan Muslims some sort of institutional authority to meet the challenges of Papua's religious and political intricacies. In fact, since the fall of Suharto and the subsequent introduction of Special Autonomy Papuan Muslims have to deal with an increasingly complex religious landscape, including a range of Indonesian Islamic figures and organisations that have discovered Papua as a destination for missionary activities (Noor 2010; Imroatus 2011; Wekke 2013), and with assertions of a heavily Christian-inflected Papuan nationalism. Countering notions that associate Islam with Indonesia and Papua with Christianity, Papuan Muslims try to reposition themselves by refusing to be relegated to the fringes of an Indonesian Islam or a Papuan nationalism, just as Papuan interpretations of Islam put the land of Papua at the very centre of this religion. It remains to be seen to what extent these attempts will be met with success or which new frictions they might generate. This is certainly a dynamic field, but for 
now, it seems, we should not expect that the spatio-temporal hierarchisations examined in this chapter will fade away too quickly, as they are inscribed in frontier notions that are firmly anchored in the persistent evolutionist-cumdevelopmentalist discourses so widespread in Indonesia.

\section{References}

Ahmad, Aziz 1976. 'The Shrinking Frontiers of Islam'. International Journal of Middle East Studies 7(2): 145-159.

Alatas, Ismail Fajrie 2005. 'Land of the Sacred, Land of the Damned: Conceptualizing Homeland among the Upholders of the Tariqa Alawiyya in Indonesia'. Antropologi Indonesia 29(2): 142-158.

Alatas, Ismail Fajrie 2010. 'A New Resurgence? The Ba'alawi and Islamic Revival in Post-Soeharto Indonesia'. Conference paper 'Islam, Trade and Culture: The Roles of the Arabs in Southeast Asia', National University of Singapore, 10-11 April 2010; http://rihlah.nl.sg/Paper/Ismail\%20Fajrie\%20Alatas.pdf.

Al-Hamid, Idrus 2013. 'Islam Politik di Papua: Resistensi dan Tantangan Membangun Perdamaian'. Jabal Hikmah 6(11): 421-441.

Al-Hamid, Idrus 2014. Jayapura dalam Transformasi Agama dan Budaya: Memahami Akar Konflik Kristen-Islam di Papua. PhD thesis, Universitas Gadjah Mada, Yogyakarta.

Azra, Azyumardi 2000. 'Hadrami as Educators: Al Habib Sayyid Idrus ibn Salim al-Jufri (1889-1969)'. Kultur. The Indonesian Journal for Muslim Cultures 1(1): 91-104.

Baumann, Gerd 2004. 'Grammars of Identity/Alterity: A Structural Approach'. In Baumann, Gerd and Gingrich, Andre (eds), Grammars of Identity/Alterity: A Structural Approach. New York and Oxford: Berghahn Books, 18-50.

Clarence-Smith, William G. 1998. 'The Economic Role of the Arab Community in Maluku, 1816 to 1940'. Indonesia and the Malay World 26(74): 32-49.

Dove, Michael 1985. 'The Agroecological Mythology of the Javanese and the Political Economy of Indonesia'. Indonesia 39: 1-36.

Dunn, Ross E. 2005. The Adventures of Ibn Battuta. A Muslim Traveler of the 14th Century. Berkeley: University of California Press.

Ellen, Roy 1996. 'Arab Traders and Land Settlers in the Geser-Gorom Archipelago'. Indonesia Circle 70: 237-252. 
From 'Stone-Age' to 'Real-Time'

Ellen, Roy 2003. On the Edge of the Banda Zone: Past and Present in the Social Organisation of a Moluccan Trading Network. Honolulu: University of Hawai'i Press.

Fold, Niels and Hirsch, Philip 2009. 'Re-thinking Frontiers in Southeast Asia'. Geographical Journal 175(2): 95-97.

Freitag, Ulrike and Clarence-Smith, William (eds) 1997. Hadhrami Traders, Scholars and Statesmen in the Indian Ocean, 1750s-1960s. Leiden: Brill.

Gingrich, Andre 2010. 'Blame it on the Turks: Language Regimes and the Culture of Frontier Orientalism in Eastern Austria'. In de Cillia, Rudolf, Gruber, Helmutm, Krzyzanowski, Michał, and Menz, Florian (eds), Diskurs-PolitikIdentität/Discourse - Politics - Identity. Stauffenburg: Tübingen, 71-81.

Heiss, Johann and Feichtinger, Johannes 2013. 'Distant Neighbors: Uses of Orientalism in the Late Nineteenth-Century Austro-Hungarian Empire'. In Hodkinson, James, Walker, John, Mazumdar, Shaswati, and Feichtinger, Johannes (eds), Deploying Orientalism in Culture and History. From Germany to Central and Eastern Europe. Rochester, New York: Camden House, 148165.

Ho, Engseng 2004. 'Empire through Diasporic Eyes: A View from the Other Boat'. Comparative Studies in Society and History 46(2): 210-246.

Ho, Engseng 2006. The Graves of Tarim. Genealogy and Mobility across the Indian Ocean. Berkeley: University of California Press.

Imroatus, Nur 2011. 'Yang Radikal dan Yang Moderat di Papua: Membangun Institusi Perdamaian di Masjid Raya Baiturrahim'. In Al-Makassary, Ridwan, Fauzia, Amelia, and Abubakar, Irfan (eds), Masjid dan Pembangunan Perdamaian. Studi Kasus Poso, Ambon, Ternate, dan Jayapura. Jakarta: Center for the Study of Religion and Culture, 273-327.

International Crisis Group 2006. 'Papua: The Dangers of Shutting Down Dialogue'. Asia Briefing $N^{\circ} 47$.

International Crisis Group 2008. 'Indonesia: Communal Tensions in Papua'. Asia Report $N^{\circ} 154$.

Jonge, Huub de 2004. 'Abdul Rahman Baswedan and the Emancipation of the Hadhramis in Indonesia'. Asian Journal of Social Science 32(3): 373-400.

Jonge, Huub de and Kaptein, Nico (eds) 2002. Transcending Borders. Arabs, Politics, Trade and Islam in Southeast Asia. Leiden: KITLV Press. 
Kaartinen, Timo 2010. Songs of Travel, Stories of Place. Poetics of Absence in an Eastern Indonesian Society. Helsinki: Academia Scientiarum Fennica.

Kahn, Joel 2012. 'Islam and Capitalism in the Frontiers and Borderlands of the Modern Malay World'. In Mee, Wendy and Kahn, Joel (eds), Questioning Modernity in Indonesia and Malaysia. Singapore: NUS Press in association with Kyoto University Press, 21-59.

Khatab, Sayed 2006. The Political Thought of Sayyid Qutb: The Theory of Jahiliyyah. London and New York: Routledge.

Kirksey, Eben 2012. Freedom in Entangled Worlds: West Papua and the Architecture of Global Power. Durham and London: Duke University Press.

Li, Tania Murray 1999. 'Marginality, Power and Production: Analysing Upland Transformations'. In Tania Murray Li (ed.), Transforming the Indonesian Uplands: Marginality, Power and Production. London: Routledge, 1-46.

Li, Tania Murray 2001. 'Relational Histories and the Production of Difference on Sulawesi's Upland Frontier'. Journal of Asian Studies 60(1): 41-66.

Lee, Samuel 2004 [1829]. The Travels of Ibn Battuta in the Near East, Asia and Africa 1325-1354. Mineola, New York: Dover Publications.

McCarthy, John and Cramb, R.A. 2009. 'Policy Narratives, Landholder Engagement, and Oil Palm Expansion on the Malaysian and Indonesian Frontiers'. Geographical Journal 175(2): 112-123.

Nisa, Eva F. 2012. 'The Voice of Syarifah on Jakarta's Da'wa Stage'. RIMA: Review of Indonesian and Malaysian Affairs 46(1): 55-81.

Noor, Farish A. 2010. 'The Arrival and Spread of the Tablighi Jama'at in West Papua (Irian Jaya), Indonesia'. RSIS Working Paper No. 191, Singapore: S. Rajaratnam School of International Studies.

Onim, Jusuf Fredrik 2006. Islam \& Kristen di Tanah Papua. Meniti Jalan Bersama Hubungan Islam-Kristen Dalam Sejarah Penyebaran dan Perjumpaannya di Wilayah Semenanjung Onin Fakfak. Bandung: Jurnal Info Media.

Pamungkas, Cahyo 2008. Papua Islam dan Otonomi Khusus: Kontestasi Identitas di Kalangan Orang Papua. Tesis Program Paskasarjana Sosiologi, Universitas Indonesia.

Pamungkas, Cahyo 2011. 'Muslim Papua and Special Autonomy: The Identity Contest in Papua'. Journal of Indonesian Social Sciences and Humanities 4: 133-155. 
From 'Stone-Age' to 'Real-Time'

Remijsen, Albert 2002. Word-prosodic Systems of Raja Ampat Languages. PhD thesis, University of Leiden.

Rutherford, Danilyn 2003. Raiding the Land of the Foreigners: The Limits of the Nation on an Indonesian Frontier. Princeton: Princeton University Press.

Rutherford, Danilyn 2012. Laughing at Leviathan: Sovereignty and Audience in West Papua. Chicago and London: The University of Chicago Press.

Slama, Martin 2011. 'Translocal Networks and Globalisation within Indonesia. Exploring the Hadhrami Diaspora from the Archipelago's North-East'. Asian Journal of Social Science 39(3): 238-257.

Slama, Martin 2012. "Coming Down to the Shop": Trajectories of Hadhrami Women into Indonesian Public Realms'. The Asia Pacific Journal of Anthropology 13(4): 313-333.

Spyer, Patricia 2000. The Memory of Trade: Modernity's Entanglements on an Eastern Indonesian Island. Durham and London: Duke University Press.

Stasch, Rupert 2011. 'Textual Iconicity and the Primitivist Cosmos: Chronotopes of Desire in Travel Writing about Korowai of West Papua' . Journal of Linguistic Anthropology 21(1): 1-21.

Tsing, Anna Lowenhaupt 2005. Friction. An Ethnography of Global Connection. Princeton and Oxford: Princeton University Press.

Wanggai, Toni Victor M. 2008. Rekonstruksi Sejarah Umat Islam di Tanah Papua. $\mathrm{PhD}$ thesis, Universitas Islam Negeri Syarif Hidayatullah.

Warnk, Holger 2010. 'The Coming of Islam and Moluccan-Malay Culture to New Guinea c.1500-1920'. Indonesia and the Malay World 38(110): 109-134.

Warta, Christian 2011. Religiositäten in Bewegung: Adat, Schriftreligionen und Nationalismen in Papua, Indonesien. PhD thesis, University of Vienna.

Wekke, Ismail Suardi 2013. 'Religious Education and Empowerment: Study on Pesantren in Muslim Minority West Papua'. MIQOT XXXVII (2): 374-395.

Widjojo, Muridan 2009. The Revolt of Prince Nuku: Cross-cultural Alliancemaking in Maluku, c.1780-1810. Leiden: KITLV.

Zadeh, Travis 2011. Mapping Frontiers Across Medieval Islam: Geography, Translation and the 'Abbasid Empire. London and New York: I.B. Tauris. 
This text is taken from From 'Stone-Age' to 'Real-Time': Exploring Papuan Temporalities, Mobilities and Religiosities, edited by Martin Slama and Jenny Munro, published 2015 by ANU Press, The Australian National University, Canberra, Australia. 